\title{
On the $110^{\text {th }}$ birth anniversary and the $60^{\text {th }}$ death anniversary of the mammologist Anna Semyonovna Stroganova (1911-1961)
}

\author{
Elena P. Tikhonova
}

ABSTRACT. The article considers the biography of Anna Semyonovna Stroganova (Evdonina) a specialist in the field of ecology and faunistics of mammals, Candidate of Biological Sciences, a researcher at the Zoological Institute of the USSR Academy of Sciences (ZIN). The article provides information about the family, education at the Leningrad State University (1929-1933), work at the Leningrad CommercialBiological Zonal Station (1932-1941), and the Zoological Institute of the USSR Academy of Sciences (1941-1961). The nature of A.S. Stroganova's work is described to study the ecology of commercial mammals and methods for predicting the dynamics of their numbers to justify fur harvesting in the country and quotas for the permissible withdrawal of resources. The period of her life in the ZIN in the first year of the Great Patriotic War, summer evacuation to Elabuga and then to Stalinabad in 1942, work in Tajikistan and return to Leningrad, restoration work at the Institute and scientific activity in the post-war years are considered in sufficient detail. A.S. Stroganova researched the ecology of commercial mammals and devised methods for predicting the dynamics of their numbers. She also studied the faunistics of mammals in the trans-Volga region and the possibility of changes in fauna because of agricultural afforestation and irrigation. A.S. Stroganova published more than 20 research papers. Unfortunately, her life ended way too soon. She only had half a century to live and did not manage to finish many of her projects or publish all of the articles she wrote.

How to cite this article: Tikhonova E.P. 2021. On the $110^{\text {th }}$ birth anniversary and the $60^{\text {th }}$ death anniversary of the mammologist Anna Semyonovna Stroganova // Russian J. Theriol. Vol.20. No.2. P.215-222. doi: 10.15298/rusjtheriol.20.2.10

KEY WORDS: Zoological Institute of the USSR Academy of Sciences, history of zoology, Stroganova Anna Semyonovna, anniversary.

Elena P. Tikhonova [Elena.Tikhonova@zin.ru; eltikh@gmail.com], Zoological Institute, Russian Academy of Sciences, Universitetskaya nab., 1, Saint-Petersburg 199034, Russia.

\section{К 100-летию со дня рождения и 60-летию со дня смерти териолога Анны Семёновны Строгановой}

\section{Е.П. Тихонова}

РЕЗЮМЕ. В статье рассмотрена биография кандидата биологических наук Анны Семёновны Строгановой (Евдониной), научного сотрудника Зоологического института АН СССР (ЗИН), специалиста в области экологии и фаунистики млекопитающих. Приведены сведения о семье, обучении в Ленинградском государственном университете (1929-1933), работе на Ленинградской зональной охотничье-промысловой станции (1932-1941) и в Зоологическом институте АН СССР (1941-1961). Описан характер работ А.С. Строгановой в области экологии промысловых млекопитающих и методики прогноза динамики их численности. Особенно детально рассмотрена ее жизнь в ЗИН АН СССР в первый год Великой Отечественной войны, летняя эвакуация в Елабугу, а затем в Сталинабад, работа в Таджикистане и возвращение в Ленинград, а также восстановительные работы в институте и научная деятельность в послевоенные годы. Охарактеризован спектр исследовательских работ А.С. Строгановой и приведен список ее научных публикаций. Начав свою трудовую деятельность в 1932 г. на базе Ленинградской зональной промыслово-биологической станции, Анна Семёновна в начале Великой Отечественной войны перешла в Зоологический институт АН СССР, где вела научные исследования в течение 20 лет. Вместе с другими сотрудниками ЗИН она спасала научные коллекции во время блокады, защищала здание ЗИН от бомбардировок, работала в Таджикистане во время эвакуации, принимала участие в восстановительных работах после окончания войны. А.С. Строганова изучала экологию промысловых млекопитающих и разрабатывала методики прогноза динамики их численности, исследовала фауну млекопитающих Заволжья и перспективы ее изменения в связи с 
полезащитным лесоразведением и орошением. Она опубликовала более 20 научных работ. К сожалению, слишком рано оборвалась ее жизнь. Ей было отпущено всего полвека земного существования. Многие ее проекты остались нереализованными, и даже не все написанные ею статьи опубликованы.

КЛЮЧЕВЫЕ СЛОВА: Зоологический институт АН СССР, история зоологии, Строганова Анна Семёновна, юбилей.

In 2021 we celebrate the $110^{\text {th }}$ birth anniversary of Anna Semyonovna Stroganova (Evdonina), a specialist in the field of ecology and faunistics of mammals, Candidate of Biological Sciences, a researcher at the Zoological Institute of the USSR Academy of Sciences (Fig. 1). Since her death 60 years have passed, and the new generation probably would not recognize this name. Anna Semyonovna was devoted to her work and had tirelessly contributed to zoological science during the hard years before, during and after the war. We tried our best to describe the life's journey of this fantastic scientist, Anna Semyonovna Stroganova, a wonderful person and an experienced field scientist who loved nature and animals with all her heart.

Anna Semyonovna Stroganova was born in Saint Petersburg on June 15, 1911. In her autobiography, written on July 5,1951 , she mentioned July 15 as her birth date. It was most likely a simple mistake since all other documents show June 15 as a real birth date. Her father, Semyon Viktorovich Evdonin, was born in 1885 in the Klemushino Village of Kirillovsky Uyezd in Novgorod Province ${ }^{1}$. He was a peasant and a seasonal worker ${ }^{2}$ until 1914, and an employee from 1914 to 1917. He died in 1917, when Anna was only six years old. Her mother, Anisya Vasil'evna, was born in 1887 and was working as a seamstress. There were four children in the family, one boy and three girls.

Until 1927 Anna Evdonina was living in the Klemushino Village, her father's birthplace, and graduated from a seven-year school there. After that, she moved to Leningrad, graduated from the $9^{\text {th }}$ grade $^{3}$ and enrolled at Leningrad State University to study biology. She graduated from the university in 1933 with a degree in Vertebrate Zoology. Even as a student, in May 1932, Anna Semyonovna started working as a laboratory assistant on the Leningrad Commercial-Biological Zonal Station ${ }^{4}$. After graduating from the University she became a junior research scientist in May 1933 and later a senior research scientist. While working on the station, Anna Semyonovna went on several expeditions: on Kola

\footnotetext{
${ }^{1}$ By the contemporary administrative division it is the Klemushino Village of Kirillovsky District in Vologda Region.

${ }^{2}$ Seasonal work was a temporary work for the Russian Empire peasants in places outside of their permanent residency.

${ }^{3}$ In 1920s there were two levels of formal education: four years of elementary education and five years of secondary-level education.

${ }^{4}$ Leningrad Commercial-Biological Zonal Station was established by G.G. Doppelmayr in 1931. It was dedicated to the scientific research of biology and ecology of fur-bearing animals, their acclimatization and reacclimatization, and also to organization of commercial hunting within the Leningrad and Murmansk regions and in Karelia.
}

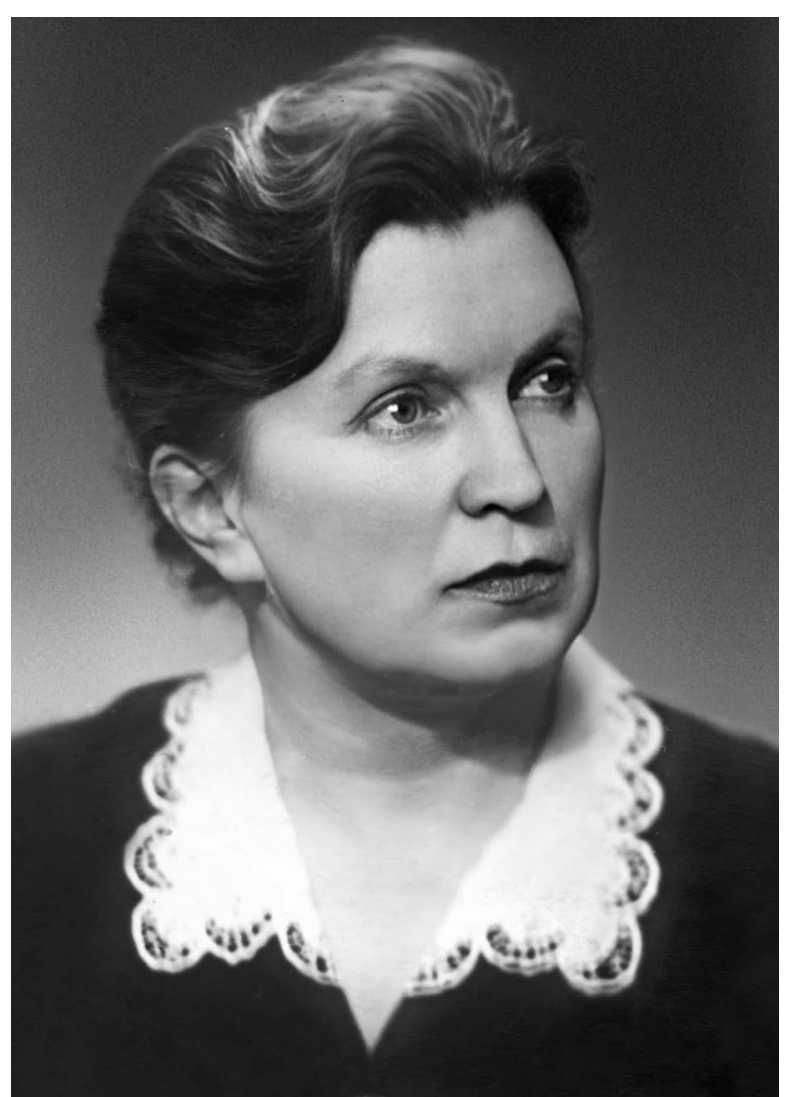

Fig. 1. Anna Semyonovna Stroganova (1911-1961).

Peninsula, in Karelo-Finnish Soviet Socialist Republic, and in Leningrad Region. Most of her research was dedicated to studying the biology of squirrels, especially their food reserves, nutrition, reproduction, population's waves, age composition of the populations, illnesses and parasites. Aside from that, she was researching biology of commercial mammals: mountain hare, muskrat, mink, stoat, and fox. During these years, A.S. Evdonina completed a number of studies, uncovering a lot of useful and important information that was a significant help in understanding the ecology of trade mammals (Evdonina, 1934, 1936).

In 1936, Sergei Ul’yanovich Stroganov (1904-1960) arrived to Leningrad from Moscow to complete his doctoral postgraduate studies at the Zoological Institute of the USSR Academy of Sciences. Then he married Anna Semyonovna. Therefore, in 1938 she started using the surname Stroganova in her publications. Anna Semyonovna, summarizing her research on the ecology of squirrels conducted over a number of years, identified 
patterns that determine the dynamics of the squirrel population in the Leningrad Region (Stroganova, 1938) and also determined that different ratio of young to adult specimen in age structure of squirrel population can be used for making predictions of this commercial animal's "harvest" waves, as valid criteria for evaluating natural increase in numbers of species in question (Stroganova, 1941).

At the beginning of the Great Patriotic War, Anna Semyonovna's husband S.U. Stroganov, deputy director at the Zoological Institute of the USSR Academy of Sciences (ZIN), enrolled in the Leningrad militia army. After he left for active service, A.S. Stroganova left her previous position and started working at ZIN as a junior research scientist in the Terrestrial Vertebrate Department, since ZIN was planning to send employees "on the periphery". However, the evacuation planned for July 1941 did not happen, and many ZIN employees, including Anna Semyonovna, remained in Leningrad. She arduously participated in relocating the Terrestrial Vertebrate Department collections to the lower levels of the building where they could be better preserved, as well as in preparing ZIN for evacuation, moving sand and water to the upper levels and the loft, so they could be used for snuffing out incendiary bombs, bringing in coal for furnaces during wintertime, and working "on civilian duty" on defensive lines construction near the Village Ust'e in Gdovsky Uyezd.

A.S. Stroganova spent the winter of 1941-1942 in blockade Leningrad. Along with other female ZIN employees, she kept bombshelter under the building in order. In the middle of March 1942 local air defense (MPVO) resumed its work after the break in JanuaryFebruary 1942 that was caused by dire conditions of worn out, hunger-bit employees. Anna Semyonovna was posted in the upper hall of the right wing, over the Museum (part of ZIN). She was in charge of all the keys of the upper hall and its rooms, and was giving them out to employees who had to write their surname in a special key book. While working in this position, she was responsible for checking fire extinguishing appliances and equipment, making sure they are always available. During air raid alarm Anna Semyonovna, with a respirator at the ready, hurried to the middle of the hall, so she could better control the situation on the flanks. A person on this duty was in command and replaced the main crossing guard if they were absent. Anna Semyonovna was on this duty one day in every six days for whole 24 hours, from 9:00 AM to 9:00 AM. She was also on duty in hospital, where she cared for the wounded patients. In the end of April 1942 ZIN reinstated a self-defense group, consisting of four squads: firefighting, medical, chemical and emergency-oriented. A.S. Stroganova became a part of the firefighting squad and was on duty on the roof of the building along with her teammates during enemy air attacks.

Even in these trying times the scientific work in ZIN continued. Considering the needs in the time of war, in 1942 the Institute settled on the theme of researching animals that could be useful to people in this situation. Scientists were planning to concentrate on the least researched groups and compose field guides for practical use. A.S. Stroganova also participated in this research. Her husband, S.U. Stroganov, was wounded and shell-shocked in war, and after hospital treatment was demobilized from the Red Army. On February 23, 1942 , he returned to his position as a deputy director in ZIN, and on April 14 became a head of the Mammals Department.

By the summer of 1942 most of ZIN employees already left Leningrad, moving to Stalinabad ${ }^{5}$, Kazan, Borok, Astrakhan and other USSR cities, towns or villages. On July 12, 1942, a group consisting of 21 ZIN employees, including Anna Semyonovna and Sergei Ul'yanovich Stroganov, left the Leningrad city. They arrived at Arzamas on July 22 and soon made their way to Kazan, where they were greeted by another deputy director of ZIN, Nikolai Timofeevich Ukhin (1891-1956), who helped them settle in Yelabuga. In the beginning of September, as soon as ZIN employees became accustomed to their new way of life, a new order was passed: to evacuate them further, to Tajikistan. It was a decision made by Sovnarkom, a Council of People's Commissars, on August 27, 1942. Sovnarkom ordered for ZIN employees to stay in Tajikistan until the end of the Great Patriotic War, and so they had to take the road again.

ZIN employees finally reached Stalinabad on November 6, 1942, when days were still warm and sunny, but nights kept getting colder, and there was already snow laying in the mountains. The main problem was to find places for everyone to live. Some of the new arrivals were severely ill. After all, the way there was a long and tedious one, and the entire journey took them almost four months. It was not easy to adapt and resume scientific work in a new place. At first, ZIN employees did not have their own work building in evacuation, so they were forced to work either from home, or on the territories of other institutions. They dedicated most of their time to field research.

During 1942-1944 A.S. Stroganova was researching commercial animals. She conducted her research in south Tajikistan, in the valley of the Vakhsh River and in Tigrovaya Balka (Fig. 2). Anna Semyonovna examined standing of the desert hare, peculiarities of its moving patterns, circadian cycle, habitat preferences, nutrition, reproduction and population dynamic (Stroganov \& Stroganova, 1944). Apart from that, in the summer of 1943 and 1944, she was working with the ZIN field party that was conducting ecological and faunalogical research in Kuibyshevskyi District in Tajikistan. The field party included many different zoologists: mammalogists Boris Stepanovich Vinogradov (1891-1958), S.U. Stroganov and A.S. Stroganova, herpetologist Sergei Aleksandrovich Chernov (19031964), entomologist Aleksandr Nikolaevich Kirichenko (1884-1971), hydrobiologists Vera Yakovlevna Pankratova (1908-1991) and Anastasia Venediktovna

${ }^{5}$ Dushanbe, a capital of Tajikistan, was known as Stalinabad from 1929 to 1961. 


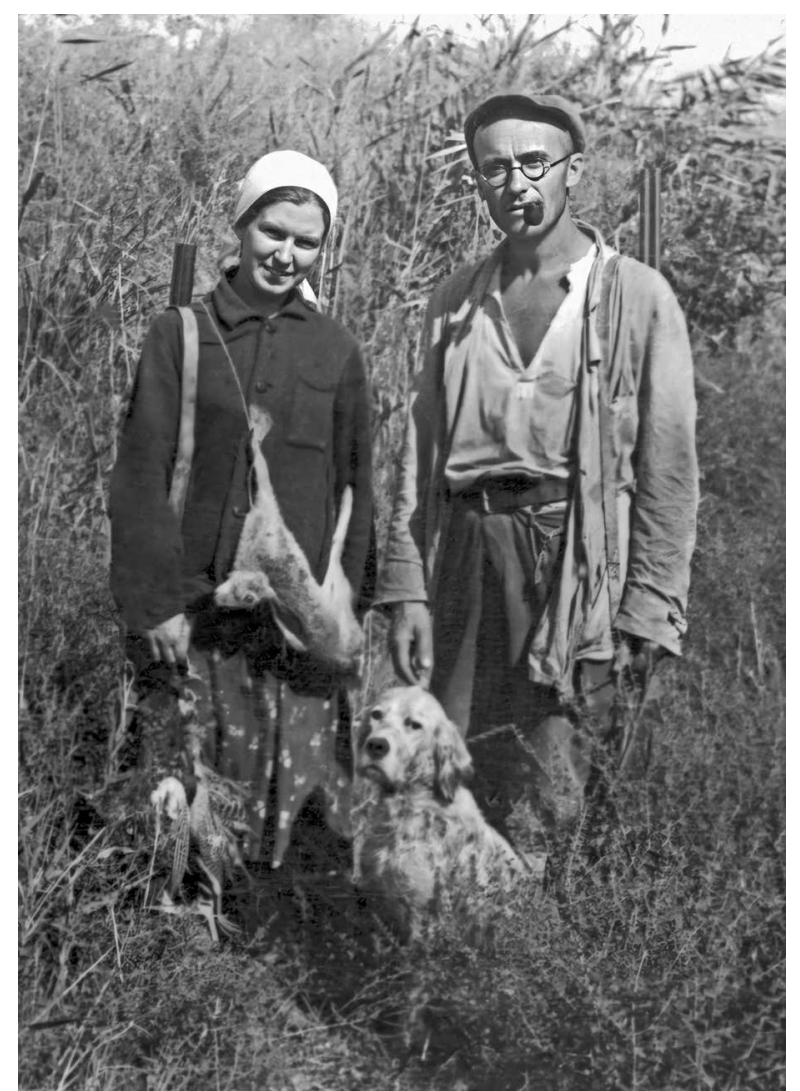

Fig. 2. Anna Semyonovna and Sergei Ul'yanovich Stroganov after a successful hare hunting. Tajikistan, 1942-1944.

Grib (1911-1950). Anna Semyonovna studied ecology of Bactrian deer together with her husband. They made six trips through the whole valley of lower Vakhsh River, and the durations of said trips differed from five days to a month and a half. S.U. Stroganov reported the results of these research trips on the ZIN annual reporting conference that took place in Stalinabad on April $10^{\text {th }}$ and $11^{\text {th }}, 1945$ (Stroganov, 1945). They both worked on the study of Tajik black-and-golden pheasant (Phasianus colchicus bianchii) reproduction, but it was published under his authorship only (Stroganov, 1946).

In 1944, after Leningrad was freed from blockade completely, it was obvious that ZIN employees would soon be able to return to Leningrad. A.S. Stroganova left Stalinabad on October 1, 1944. Her journey was evidently not an easy one, since she only arrived at Leningrad on November 16, 1944. After that, Anna Semyonovna did not return to Tajikistan and continued working in ZIN. S.U. Stroganov remained in Soviet Central Asia for the time being. In one of the letters to his wife, he wrote: "Life here is pretty lousy lately. My health has seen better days: tuberculosis grew worse, I caught malaria, and my heart is in dreadful condition, but I work a lot, and the work is enjoyable". He returned to Leningrad only a year after, on May 12, 1945, along with other remaining forty-two ZIN employees who were previously evacuated to Stalinabad. In February
1949 he left ZIN and since then got to work in Tomsk, Stalinabad, and Novosibirsk.

In spring $1945 \mathrm{ZIN}$ was preparing to celebrate $220^{\text {th }}$ anniversary of the USSR Academy of Sciences. Employees had to put a lot of effort in restoring and repairing the Institute and the Museum. It was not an easy job, and Anna Semyonovna participated in everything: receiving ethanol for collections, removing the collections from the cellars and getting them to prime condition, shoveling the snow near the building, preparing and conducting festive events dedicated to jubilee of Mikhail Nikolaevich Rimsky-Korsakov (1873-1951), VicePresident of the Russian Entomological Society. She also was on duty in the Museum during the restoration, and a main crossing guard in the Institute. Moreover, Anna Semyonovna was in a chemical squad of a selfdefense group focused on air defense, was a forewoman in emergency jobs, etc. She received gratitude numerous times for her tireless work. Meanwhile life in ZIN started to go back to its old scientific ways. All employees returned from the evacuation, collections were moved to their original places and put in order, and the renovated Museum opened for visitors.

Anna Semyonovna researched intraspecific variability and combined the results of all her research from 1936 to 1940 considering squirrel's nutrition and population dynamics in relation to different factors, such as atmospheric changes, amount of seeds and mushrooms available each particular year, pests damaging coniferous seeds, migration, etc. She made a special emphasis on squirrel's reproduction and on predicting the population size in the upcoming years (Stroganova, 1948).

In the late 1940s-early 1950s Anna Semyonovna was taking part in a more broad faunistic research in places of agricultural afforestation and irrigation in Cis-Urals region and the trans-Volga region. "Stalin's Great Plan" asked for transformation of nature, and that is why this problem was presented to ZIN and its employees. Agricultural afforestation and irrigation had to help against droughts and allow people to use these territories for various sectors of the national economy. This could dramatically change the terrain of these dry lands and make climate in the trans-Volga region more mild, as well as changing the flora and fauna of this region. Therefore, researching these territories became a priority for all scientists, including biologists.

A.S. Stroganova, as was mentioned above, took part in this research. She quickly switched to a new subject under the leadership of professor B.S. Vinogradov. Her main goal was to survey the mammal fauna in steppe and semi-desert of the trans-Volga region and nearby territories: what said fauna consists of, its biotopical distribution, numbers and value of certain species to the economy in the irrigated lands and man-made forests in the steppe. She also wanted to make predictions considering change of this fauna in relation to the

${ }^{6}$ Stalin's plan for nature transformation, or "The great plan of transforming the nature" was going to stretch from 1949 to 1965 , but after I.V. Stalin's death in 1953 the plan was cancelled. 
"nature transformation" and give useful suggestions on how to protect saplings planted by people from rodents. Main fixed site observations were conducted in wooded steppe, in Timashevsk forest belts and semidesert on the irrigated lands of Valuyskaya Experimental Meliorative Station. She was also working on the irrigated lands of Bezenchuk Experimental Station, in the forest strips of the Bogdinskaya Experimental Station, in steppes and plantations of the midstream and the lower reaches of Yeruslan River, in Volga Region steppes and inundable plantations on the left bank of the Volga River. Experienced field scientist and researcher, A.S. Stroganova spent around eleven months during four summer seasons (from April to October 1949-1952) in different geographical zones of trans-Volga region, observing the fauna, counting the numbers and collecting animals in the field and on the routes in different habitats. She collected 1650 mammal specimens, around 2300 regurgitates of birds of prey, examples of damages and other valuable materials, characterizing life patterns of the animals and their importance to local economy. During that period, she published a series of papers dedicated to fauna of the trans-Volga region (Stroganova, 1951a, b, 1952; Stroganova \& Yudin, 1950, 1951).

As a result of all research conducted, and after comparing these observations to earlier scientific papers, A.S. Stroganova came to a conclusion that mammal fauna of steppe and semi-desert of the trans-Volga region consists of 68 species and has changed dramatically relatively recently. Some species (tarpan, onager, yellow steppe lemming), that used to be prevalent in the transVolga region steppes and nearby territories in the past, were already extinct by the time she started her research, some others (yellow ground squirrel, marmot, steppe lemming, steppe pika, saiga) became less prevalent, and borders of their habitats have changed. At the same time Anna Semyonovna noticed that other animals have expanded their habitats and have increased in numbers, namely little ground squirrel, hamster, common field mouse and house mouse, common vole, European hare and elk. Her observations made it clear that irrigated lands in steppe and semi-desert of the trans-Volga region create favourable microclimatic, foraging and protective conditions for some hygrophilous rodents, such as a common field mouse, striped field-mouse, red-backed vole, common vole and mole vole, and also for European hare, some insectivores, Chiroptera and carnivores. At the same time, xerophilous species (for example, little ground squirrel, yellow ground squirrel and jerboa) are negatively affected by agricultural afforestation and especially irrigation, and these factors lead to decrease in their numbers (Stroganova, 1953). A.S. Stroganova used these findings as a base material in her Candidate's Dissertation "Mammals of the Trans-Volga region and the possibility of changes in fauna because of agricultural afforestation and irrigation", and she successfully defended her thesis on May 8, 1953 (Stroganova, 1954).

In summer 1953, after defending her Candidate's Dissertation, A.S. Stroganova left for an expedition in ribbon forests of Semipalatinsk Region to continue her research. After this trip, she enlarged the collection of the ZIN Mammals Department by 11 spirit specimens, 27 fells, 24 skulls and 6 skeletons of rodents and insectivores from Semipalatinsk Region of Kazakh Soviet Socialist Republic (Fig. 3).

In September-October of 1954 and May-June 1955 A.S. Stroganova conducted field research and collected materials on Caucasian squirrel in Zagatala State Nature Reserve in the Azerbaijan. Moreover, she inspected Caucasian squirrel collections in ZIN, Moscow State University and zoological institutes of the Academies of Sciences in Azerbaijan and Georgia. In the paper on the Caucasian squirrel A.S. Stroganova mentioned systematic notes, described habitats of this species and their distribution, as well as their numbers, nutrition, migration, drays and hiding spots, their general behaviour and activity (Stroganova, 1958). She made a special emphasis on the Caucasian squirrel reproduction. Anna Semyonovna compared the Caucasian squirrel with nominal species in every respect and found a huge number of differences. She also generously illustrated this work with her original photographs. In 1956 ZIN received a collection of squirrels (Callosciurus and Dremomys genera), collected by the Chinese Academy of Sciences and USSR Academy of Sciences united biological expeditions. Anna Semyonovna researched this material and described five subspecies, two of which were previously unknown to China (Stroganova, 1957).

In summer 1958 ZIN received tragic news: the Mammals Department and the Terrestrial Vertebrates Department lost their supervisor, Professor B.S. Vinogradov, who was continuously leading these departments for whole 30 years. In memory of her teacher Anna Semyonovna published an obituary in Czech and Chinese (Stroganova, 1959a, b).

In August 1960 A.S. Stroganova took part in International symposium on mammals research methodology in Brno (Czechoslovakia), where she presented a report on the ecology of the relict ground squirrel $(C$. relictus) and the method of quantitative accounting of its population (Stroganova, 1962). She also published an article on systematic position of the relict ground squirrel together with postgraduate student Chzhu Dinh in the Proceedings of ZIN (Stroganova \& Chzhu Dinh, 1961).

Anna Semyonovna together with Igor Mikhailovich Gromov (1913-2003) prepared materials on genus Citellus (now Spermophilus) for "Fauna of the USSR". She conducted field researches on relict ground squirrel in a Central Tian Shan, in 1957, and on long-tailed ground squirrel in Dzungarian Alatau, in 1958 (Fig. 4). At the same time, she was collecting ecological and morphological material on other species of mammals. Anna Semyonovna wrote several essays on biology of Marmotini tribe, genus Citellus, species C. relictus and C. undulatus, and she also prepared useful information on ecology of other species, collected material on the limb skeletons of different squirrels for drawings. While researching ZIN collection of squirrels, Anna Semyonovna spent a lot of time putting them in 


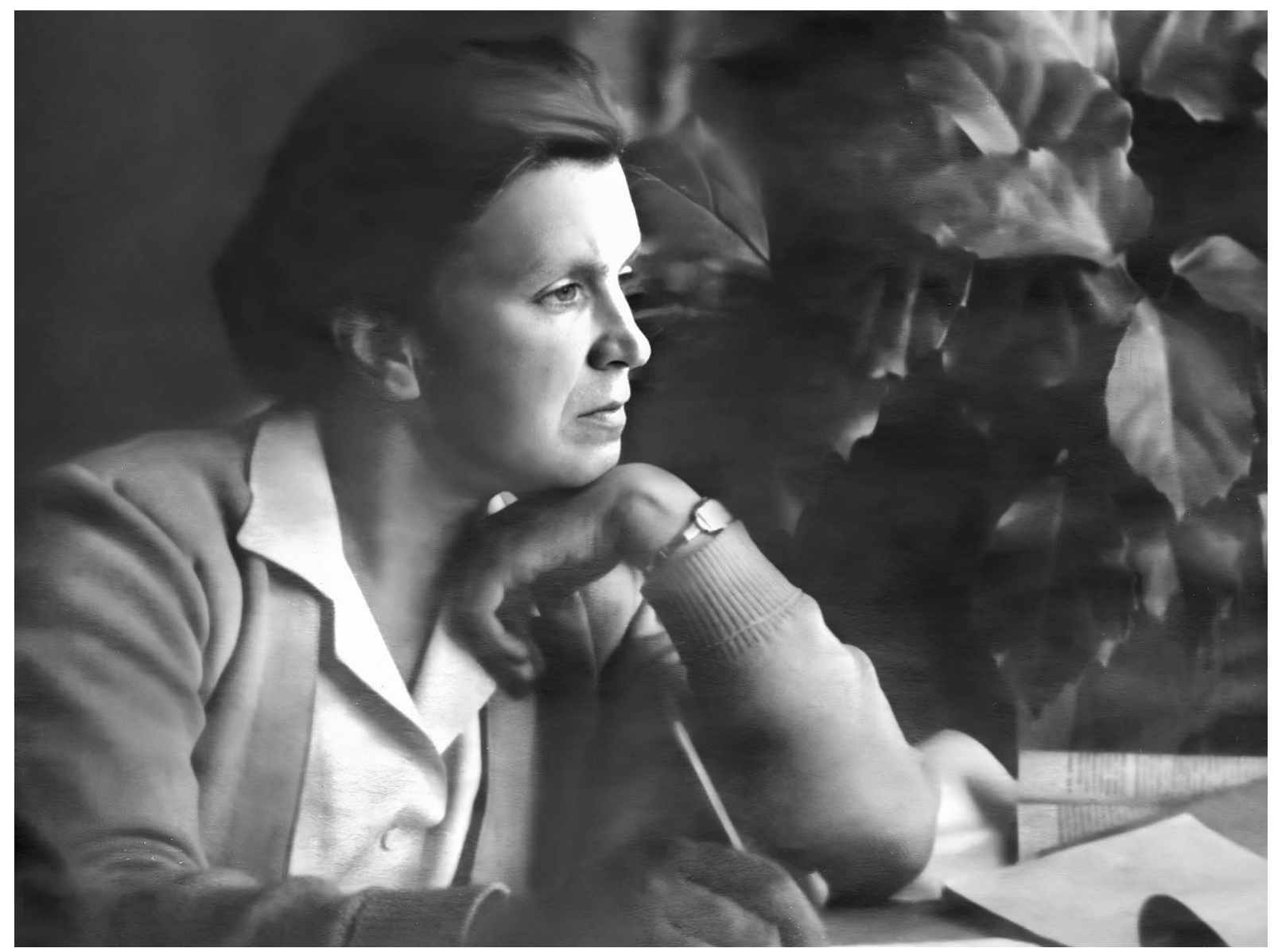

Fig. 3. Anna Semyonovna Stroganova at her desk at the Zoological Institute processes the materials obtained during the expedition to the Semipalatinsk Region. Leningrad, 1953.

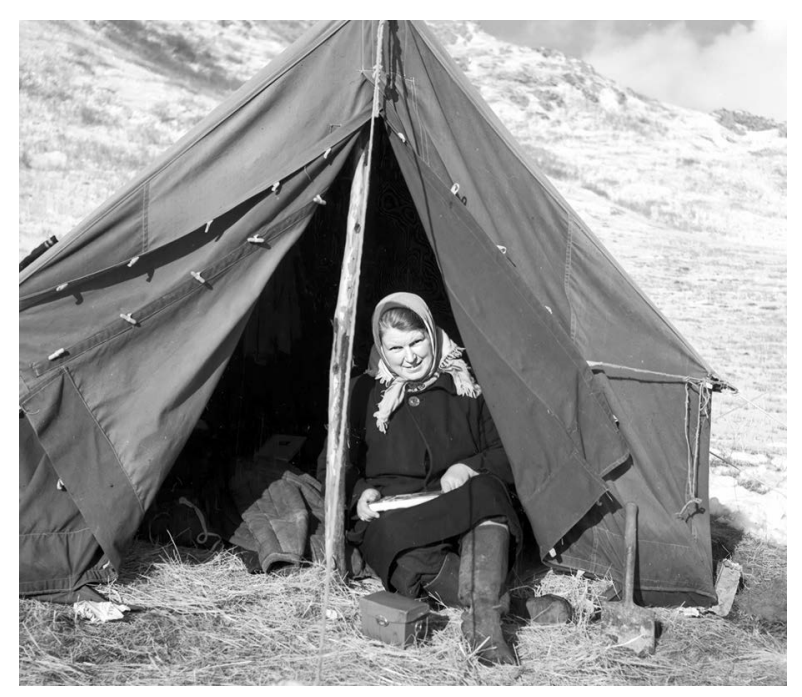

Fig. 4. Anna Semyonovna Stroganova in the expedition to the Tien Shan, 1957. systematic order and reevaluating some of gatherings. In 1959 A.S. Stroganova published an article together with some other scientists on the time and reasons for the extinction of the Caucasian marmot (Vereshchagin et al., 1959). Sadly, Anna Semyonovna could not finish her work on an issue of "Fauna of the USSR" dedicated to squirrels. After her death, I.M. Gromov enlisted the help of Dmitri Ivanovich Bibikov (1916-1997), Nikolai Ivanovich Kalabukhov (1908-1991) and Marina Nikolaevna Meyer (1927-2001) to write the monograph. Together they finished the work started by Anna Semyonovna (Gromov et al., 1965). In memory of their colleague, they concluded the text with this dedication: "In loving memory of Anna Semyonovna Stroganova, who had the idea for this monograph and was working on it in the beginning". In the book's introduction, I.M. Gromov stated that “...this monograph was meant to be a collaborative work with now deceased A.S. Stroganova, who had a lot of experience in researching biology of ground squirrels $<\ldots>$... We used drafts hand-written by A.S. Stroganova for biological essays in this book". 
Anna Semyonovna Stroganova lived a short, but hard and eventful life. She had to go through many hardships, and she lost her father early. Anna spent childhood and teen years in a secluded village in Vologda Region, in the bosom of nature, where she had the opportunity to observe animals in their natural habitat and realize how much she loves the animal world and how deeply she yearns to learn its secrets. That is why she made the decision to go to Leningrad State University. In her student years, Anna Semyonovna already started working on Leningrad Commercial-Biological Zonal Station and put all her effort into researching commercial animals of north-west. She completed a vast number of studies, and her research gave us a lot of new and valuable data for better understanding of mammalian ecology. She pinned down factors influencing a population's dynamic and found out that different ratio of young to adult specimen in age structure of a population can be used for making predictions of possible increase or decrease in numbers of said population.

After the war Anna Semyonovna went on several expeditions, collecting valuable material, defended her Candidate's Dissertation, was participating in scientific conferences in USSR and abroad, was responsible for postgraduate students, and started writing "Fauna of the USSR" on squirrels, which she unfortunately could not finish. All her works are extraordinary well done, with careful research put into it, all facts are carefully analyzed, and results are presented with great accuracy.

Anna Semyonovna did not have children, but she loved her nieces and nephews and happily dedicated her free time to them. She was a kind, sweet person, always ready to help. She gave shelter in her own house to many scientists and postgraduates who came to ZIN from other cities and did not have a place to live, or sometimes even no money to buy food. Anna Semyonovna did not turn her back on anyone and always helped every single person in need. Everyone loved Anna for her gentle nature, humane attitude, benevolence and hospitality (Fig. 5). A.S. Stroganova was working in Zoological Institute of the USSR Academy of Sciences for 20 years. She wrote more than 20 scientific papers, received the Order of the Red Banner of Labour (1954) and medals "For the Defense of Leningrad" (1945), "For Valiant Labour in the Great Patriotic War 1941-1945" (1946) and "In Commemoration of the $250^{\text {th }}$ Anniversary of Leningrad" (1957).

A.S. Stroganova was very active in the scientific society. She regularly published results of her research both in USSR and abroad. She had many creative plans, was going to travel abroad for another field trip, but her life ended abruptly, and she died on July 12, 1961 in Leningrad, soon after turning fifty. Aside from her publications, in memory of this exceptional scientist we have some documents left in the foundation of A.S. Stroganova in Scientific Archive of ZIN: handwritten papers that were not published, diaries, drawings, photographs, photographic negatives and other documents that are still waiting for their own researcher.

ACKNOWLEDGEMENTS: My heartfelt thanks for priceless advice and helpful comments goes for O.V. Zherebtsova and S.A. Sablina. I am especially thankful to A.A. Tikhonova for translating this article in English. This work was done as a part of the state assignment by ZIN Federal theme AAAA-A19-119032590102-7.

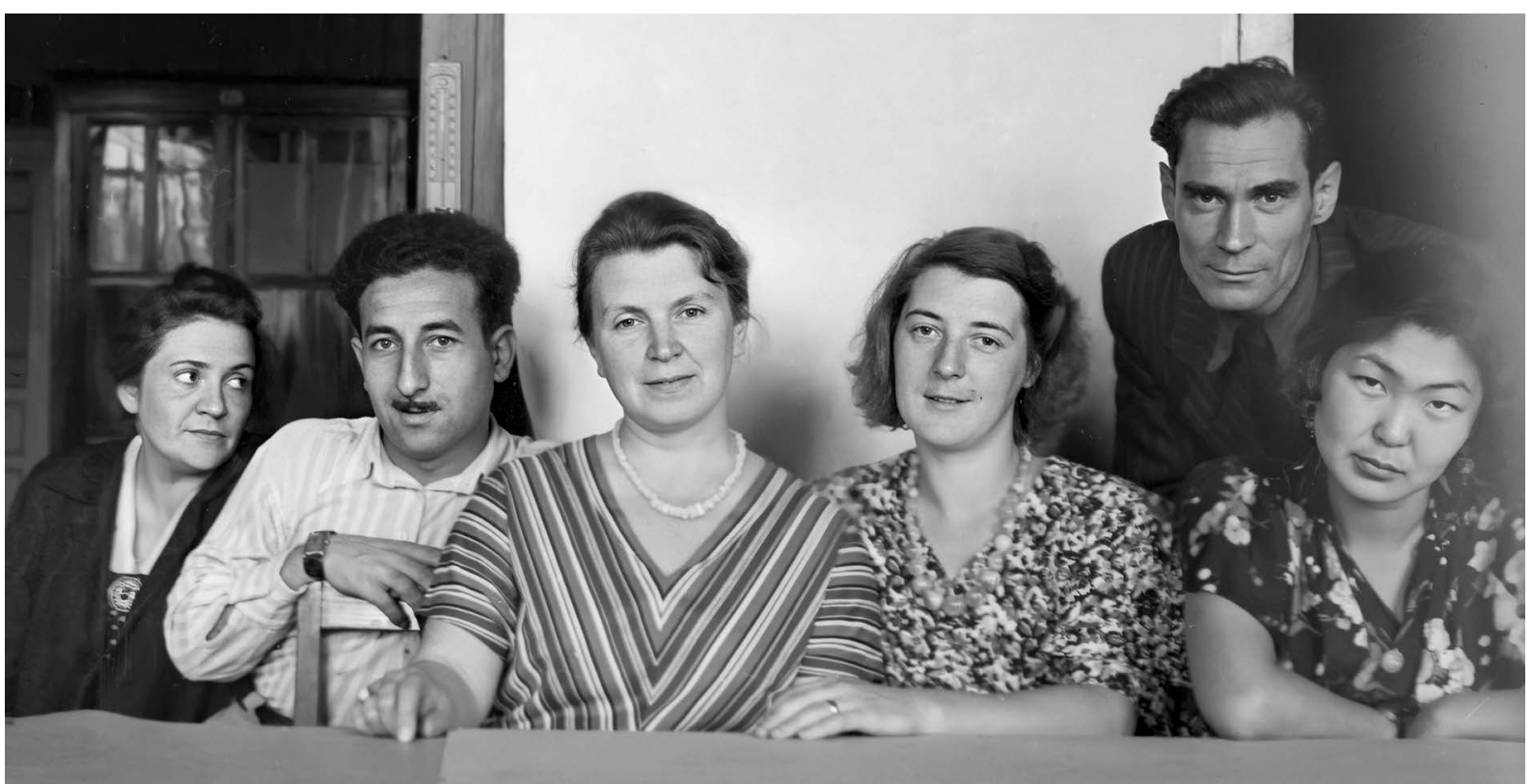

Fig. 5. Employees and postgraduates of the Mammals Department of the Zoological Institute. From left to right: Tat'yana Nikolaevna Gerakova (Zalesskaya), Khaiyam Mukhtar-ogly Alekperov, Anna Semyonovna Stroganova, Maria Nikolaevna Naumova, Oleg Vasil'yevich Yegorov, Henrietta Markhozovna Khabaeva. Leningrad, 1950s. 


\section{References}

Evdonina A.S. 1934. [Materials for the study of the biology and nutrition of squirrels in the Leningrad Region] // Promyslovaya fauna i okhotnich'e khozyaistvo Leningradskoi oblasti. Vsesoyuznyi nauchno-issledovatel'skii Institut pushnomekhovogo i okhotnich'ego khozyaistva. Leningradskaya zonal'naya promyslovaya okhotnich'ya biologicheskaya stantsiya. Moscow \& Leningrad: KOIZ. P.35-67 [in Russian].

Evdonina A.S. 1936. [Box trap for catching muskrats in spring and summer] // Za Sovetskuyu Pushninu. No.19(177). P.4. [In Russian].

Gromov I.M., Bibikov D.I., Kalabukhov N.I. \& Meyer M.N. 1965. [Ground squirrels (Marmotinae)] // [Fauna of USSR. Mammals. Vol.3. No.2]. Moscow \& Leningrad: Izdatel'stvo "Nauka". P.1-468 [in Russian].

Stroganov S.U. 1945. [Bactrian deer, or gavas, in Tajikistan] // Zoologicheskii Institut AN SSSR. Otchetnaya Sessiya. Stalinabad. April 10-11, 1945. Abstracts of Reports. P.34-35 [in Russian].

Stroganov S.U. 1946. [Materials on reproduction of the Tajik black-and-golden pheasant] // Bulleten' Moscovskogo Obshchestva Ispytatelei Prirody. Vol.51. No.2. P.73-86 [in Russian].

Stroganov S.U. \& Stroganova A.S. 1944. [Materials on the biology of the desert hare (Lepus tibetanus buchariensis Ogn.) based on the observations in Southern Tajikistan] // Izvestiya Tadzhikskogo Filiala AN SSSR. No.5. P.161-188 [in Russian].

Stroganova A.S. 1938. [Experience in forecasting fluctuations in the number of squirrels (Sciurus vulgaris) in the Leningrad Region] // Priroda. No.10. P.142-144 [in Russian].

Stroganova A.S. 1941. [Experience in analyzing the age composition of the squirrel population in the Leningrad Region] // Priroda. No.2. P.90-93 [in Russian].

Stroganova A.S. 1948. [Materials on the ecology of the squirrel (Sciurus vulgaris) in the Leningrad Region] // Trudy Zoologicheskogo Instituta AN SSSR. Vol.7. No.3. P.263-291 [in Russian].

Stroganova A.S. 1951a. [To the geographical distribution of the small shrew] // Priroda. No.3. P.64 [in Russian].

Stroganova A.S. 1951b. [The appearance of moose in the Stalingrad Region] // Priroda. No.6. P.53-54 [in Russian].

Stroganova A.S. 1952. [Fauna of mammals of irrigated lands and forest plantations of the Valuyskaya Experimental
Meliorative Station (Stalingrad Region)] // Trudy Zoologicheskogo Instituta AN SSSR. Vol.11. P.214-234 [in Russian].

Stroganova A.S. 1953. [The fauna of mammals of the TransVolga region and the prospects for its changes in connection to protective afforestation and irrigation]. Avtoreferat Dissertatsii Candidata Biologicheskikh Nauk. Leningrad: Zoologicheskii Institut AN SSSR. 16 p. [in Russian].

Stroganova A.S. 1954. [Mammals of the steppe and semi-desert of the Trans-Volga region] // Trudy Zoologicheskogo Instituta AN SSSR. Vol.16. P.30-116 [in Russian].

Stroganova A.S. 1957. [To the Sciuridae fauna of the southern part of Yunnan Province (China)] // Zoologicheskii Zhurnal. Vol.36. No.11. P.1761-1769 [in Russian, with English summary].

Stroganova A.S. 1958. [Essay on the ecology of the Caucasian squirrel Sciurus (Tunes) anomalus Güld, 1792] // Trudy Zoologicheskogo Instituta AN SSSR. Vol.25. P.304-320 [in Russian].

Stroganova A.S. 1959a. In memory of the outstanding Soviet zoologist Professor B.S. Vinogradov // Zoologicki Listy. No.3. P.289-290.

Stroganova A.S. 1959b. [In memory of the outstanding Soviet zoologist Professor B.S. Vinogradov] // Acta Zoologica Sinica. Vol.11. No.2. P.280-281 [in Chinese].

Stroganova A.S. 1962. [Peculiarities of the ecology of the relict ground squirrel (Citellus relictus Kaschkarov) and the method of quantitative accounting of its population] // Symposium Theriologicum, Brno, 1960. Praha. P.312-317 [in Russian].

Stroganova A.S. \& Chzhu Dinh 1961. [Systematic position of the relict ground squirrel (C. relictus) and materials on its ecology in the Kuuluk-Tau Mountains (Central Tien Shan)] // Trudy Zoologicheskogo Instituta AN SSSR. Vol.29. P.81-100 [in Russian].

Stroganova A.S. \& Yudin K.A. 1950. [The harmful activity of the small ground squirrel in young oak plantings of the Stalingrad Region] // Zoologicheskii Zhurnal. Vol.29. No.5. P.385-388 [in Russian].

Stroganova A.S. \& Yudin K.A. 1951. [Ground squirrels and hares as pests of oak nesting crops in the Zavolzhye region] // Zoologicheskii Zhurnal. Vol.30. No.2. P.106-110 [in Russian].

Vereshchagin N.K., Heptner V.G. \& Stroganova A.S. 1959. [On the time and reason for the extinction of the Caucasian marmot] // Nauchnye Doklady Vysshei Shkoly, Biologicheskie Nauki. No.2. P.36-38 [in Russian]. 